\title{
14. BIOMETRIC ANALYSIS OF PLANOROTALITES PSEUDOMENARDII (UPPER PALEOCENE) AT DEEP SEA DRILLING PROJECT SITE 605, NORTHWESTERN ATLANTIC ${ }^{1}$
}

\author{
A. J. Nederbragt and J. E. van Hinte, Instituut voor Aardwetenschappen, Vrije Universiteit, Amsterdam²
}

\begin{abstract}
Good faunal preservation in the upper part of the Planorotalites pseudomenardii Zone at Deep Sea Drilling Project Site 605, northwestern Atlantic, allows a biometric analysis of the upper Paleocene planktonic foraminiferal species Planorotalites pseudomenardii (Bolli), a keeled species that probably developed from a middle Paleocene unkeeled Planorotalites form. Multivariate analysis shows a consistent separation of all Planorotalites specimens into two groups, which are differentiated by the presence or absence of a complete keel; other variables are only of minor importance. The keeled group coincides with $P$. pseudomenardii. We recognize only one unkeeled species, Planorotalites chapmani (Parr), with Planorotalites ehrenbergi (Bolli), Planorotalites imitata (Subbotina), Planorotalites planoconica (Subbotina), Planorotalites troelseni (Loeblich and Tappan), and Planorotalites hausbergensis (Gohrbrandt) as junior synonyms. $P$. chapmani ranges from the middle Paleocene to at least the top of the upper Paleocene.

The morphology of $P$. pseudomenardii does not change significantly, and although the frequency of Planorotalites is variable, the proportion of $P$. pseudomenardii to all Planorotalites varies only slightly around $65 \%$ in the upper twothirds of its range at Site 605 . However, in the top $1.5 \mathrm{~m}$ of its range the proportion of $P$. pseudomenardii decreases; in the same section, all Planorotalites specimens show a reduction in the size of their tests, suggesting that a temporary change in environmental conditions led to the exit of $P$. pseudomenardii, in Magnetozone C24R at Site 605-apparently higher than expected from current standard zonations. Unkeeled Planorotalites, in contrast to $P$. pseudomenardii, persisted and regained normal size.

The entry of $P$. pseudomenardii at Site 605 cannot be described in the same detail because of low frequencies of $P l a-$ norotalites specimens and an erratic distribution of $P$. pseudomenardii in the lower part of its range. Many of the washed residues of the samples from these sediments are dominated by radiolarians, and the poorly preserved foraminiferal faunas may have abundant benthics, indicating carbonate dissolution. The initially low frequencies of $P$. pseudomenardii relative to the unkeeled Planorotalites show a strong negative correlation with the total amount of radiolarians per sample and could be the result of preferential preservation, as well as of the same environmental conditions that caused the abundance of radiolarians.
\end{abstract}

\section{INTRODUCTION}

The purpose of this study was to determine the rate and nature of the entry and exit ${ }^{3}$ of a planktonic foraminiferal species, and to describe morphological variation throughout the range of the species. Accurate knowledge of the ascent, extinction, and morphologic changes within a species should improve the reliability of highresolution biostratigraphy. Multivariate data analysis has been used as a tool.

At Hole 605, northwestern Atlantic (Fig. 1), Leg 93 drilled a nearly complete upper Paleocene pelagic section in sediments with relatively high accumulation rates ( $\sim 4 \mathrm{~cm} / 10^{3}$ years). This provided excellent material for a detailed study of Planorotalites pseudomenardii (Bolli), which had been selected because of its assumed unambiguous definition.

The genus Planorotalites ranges from the lower $\mathrm{Pa}$ leocene to the middle Eocene and can easily be distinguished from other planktonic foraminiferal genera because of its low trochospire and overall smooth appearance; its test is finely perforate and looks shiny com-

\footnotetext{
${ }^{1}$ van Hinte, J. E., Wise, S. W., Jr., et al., Init. Repts. DSDP, 93: Washington (U.S. Govt, Printing Office).

2 Address: (Nederbragt and van Hinte): vu-Instituut voor Aardwetenschappen, Box 7161,1007 MC Amsterdam, The Netherlands.

3 In this chapter the terms "entry" and "exit" are used to indicate the first and last occurrence, respectively, of these species at Site 605; "entry" and "exit" do not imply migration.
}

pared to the coarsely perforate or ornamented tests of other genera. $P$. pseudomenardii is the only keeled $\mathrm{Pa}$ leocene Planorotalites species. It probably developed from the unkeeled middle Paleocene forms.

The number of unkeeled upper Paleocene species that has been distinguished by different authors varies from one (Postuma, 1971; Stainforth et al., 1975) to five (Berggren, 1977) or seven (Blow, 1979). In the upper Paleocene section at Site 605 we could recognize six of the forms described as species in the literature: $P$. chapmani (Parr), P. ehrenbergi (Bolli), P. imitata (Subbotina), P. planoconica (Subbotina), P. troelseni (Loeblich and Tappan), and $P$. hausbergensis (Gohrbrandt).

\section{MATERIALS AND METHODS}

For this study $7220-\mathrm{cm}^{3}$ shipboard samples were available from Hole 605, Cores 57 to 45 (from the top of the Morozovella pusilla pusilla Zone to the base of the Morozovella velascoensis Zone). A pilot survey of these shipboard samples was made to locate the approximate position of the entry and exit of $P$. pseudomenardii. Two intervals were sampled in detail (Fig. 2).

All samples are from lithologic Unit IV, which consists of gray limestones and mudstones. Drilling disturbance is minimal. Though lithology does not change much, the preservation of the faunas is variable. Many samples in the lower cores (57-52) contain over $60 \%$ radiolarians, and benthic foraminifers may be abundant. Planktonic foraminifers in the washed residues of these samples are rather poorly preserved. This is at least partly due to carbonate dissolution, as indicated by the dominance of benthos in the foraminiferal faunas in some of these samples (Fig. 3). The poor preservation and erratic distribution of Planorotalites in this part of the section makes it unsuitable for detailed study of $P$. pseudomenardii and indeed also led to an initial 


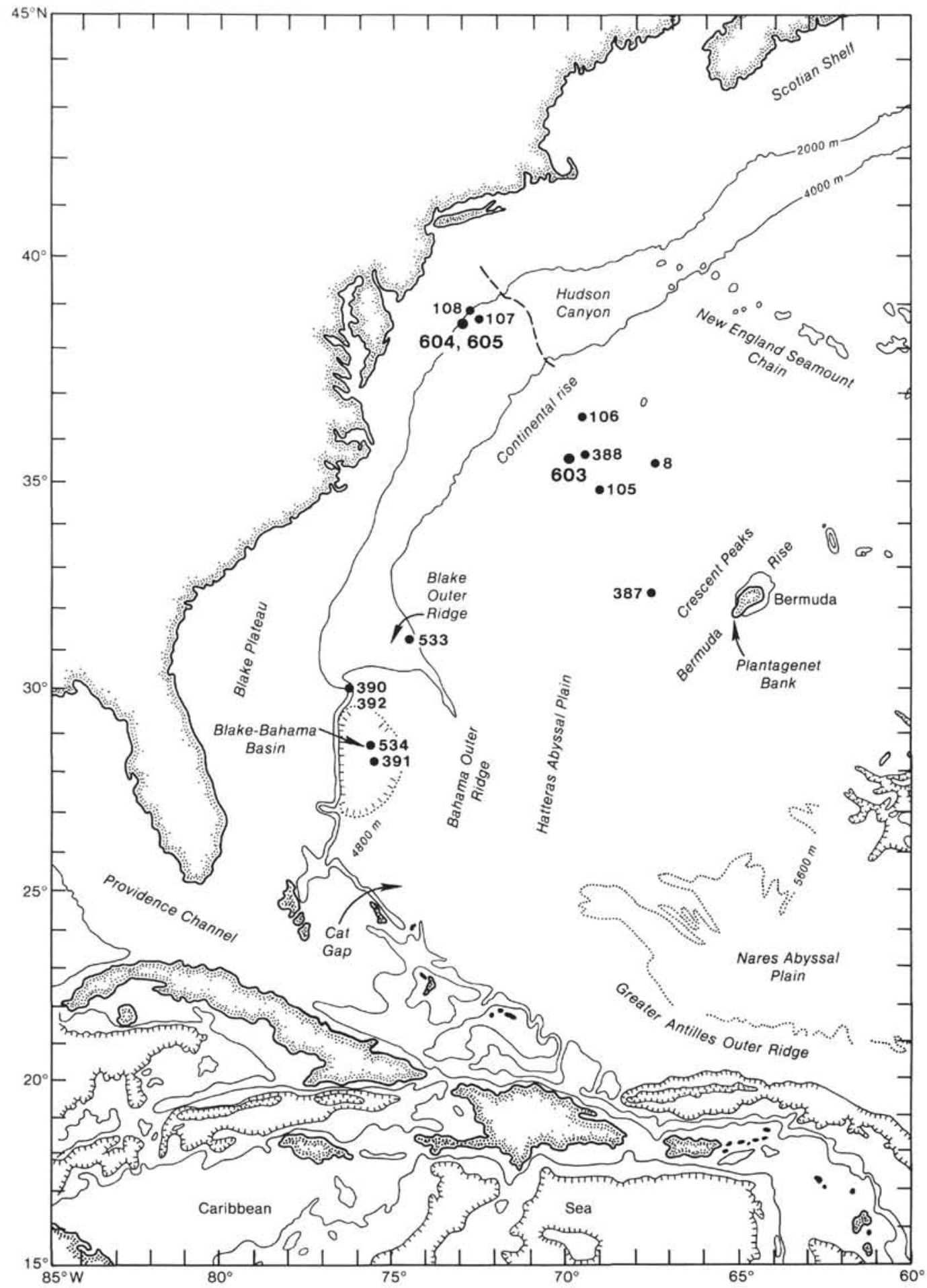

Figure 1. Map showing location of northwestern Atlantic DSDP sites (from Legs 2, 11, 43, 44, 76, and 93).

error in the location of postcruise sampling. The true entry of the species apparently occurred below the lowest sample of this detailed set, but the lack of useful material in the original samples meant that a second request was unwarranted.

Preservation improves above Core 52, and the frequencies of all planktonic foraminiferal species increase. The exit of $P$. pseudomenardii occurs within sediments containing well preserved faunas. The upper set of detailed samples allows for a good description of this exit (10- $\mathrm{cm}^{3}$ samples at $10-\mathrm{cm}$ intervals from 605-46-3, 0-5 $\mathrm{cm}$ to $605-46-4$, $145-149 \mathrm{~cm})$. Sediment accumulation rates were relatively high for the 80-m-thick section of pelagic sediments that constitutes the $P$. pseudomenardii Zone, approximately $4 \mathrm{~cm} / 10^{3}$ years using the time scale of Vail and Mitchum (1979). Assuming that these accumulation rates were constant, a 1 -cm-thick sample would contain a 250 -year record, and sampling every $10 \mathrm{~cm}$ (as was done around the exit) implies that any changes can be recorded with a resolution of 2500 years.

All samples were disintegrated by impregnation with petroleum ether and subsequent immersion in boiling water. In our experience this drastic method gives good results when dealing with the rather hard limestone of these cores. They were washed over a $63-\mu \mathrm{m}$ sieve and dry 


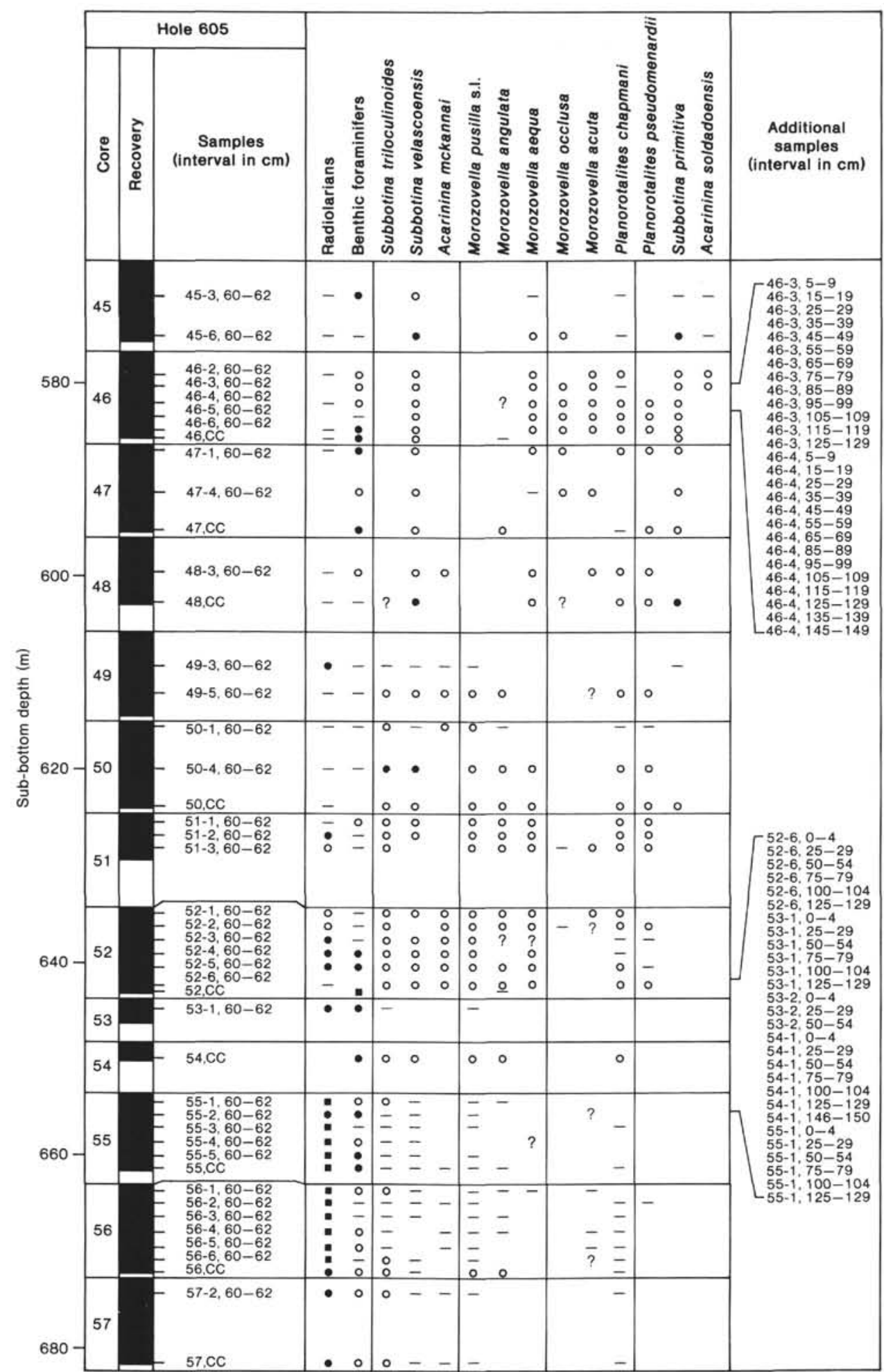

Figure 2. Pilot distribution chart of planktonic foraminifers in the upper Paleocene shipboard samples from Site 605. Also shown is the position of two sets of additional samples. For species description, see Stainforth et al. (1975). Relative abundance: $\mathbf{m}=$ dominant; $\bullet=$ abundant; $0=$ common; $-=$ rare; $?$ = questionable.

sieved over a $125-\mu \mathrm{m}$ mesh screen. When necessary, residues were split to get workable amounts. The material has been filed in the micropaleontological collection of the Free University in Amsterdam.

To quantitatively describe morphologic variation of Planorotalites, the following nine variables were determined (see Fig. 4.): (1) length, the maximum diameter of the test; (2) width, measured from the base of the last chamber over the center of the umbilicus; (3) base length of the last chamber; (4) peripheral width of the penultimate chamber; (5) width of the umbilicus measured as the distance between the umbilical shoulders of the last chamber and its opposite; (6) portion of the suture of the penultimate chamber that is limbate (in Fig. 4B this is $40 \%$ ); (7) number of keeled chambers in the last whorl (in Fig. 4B this 


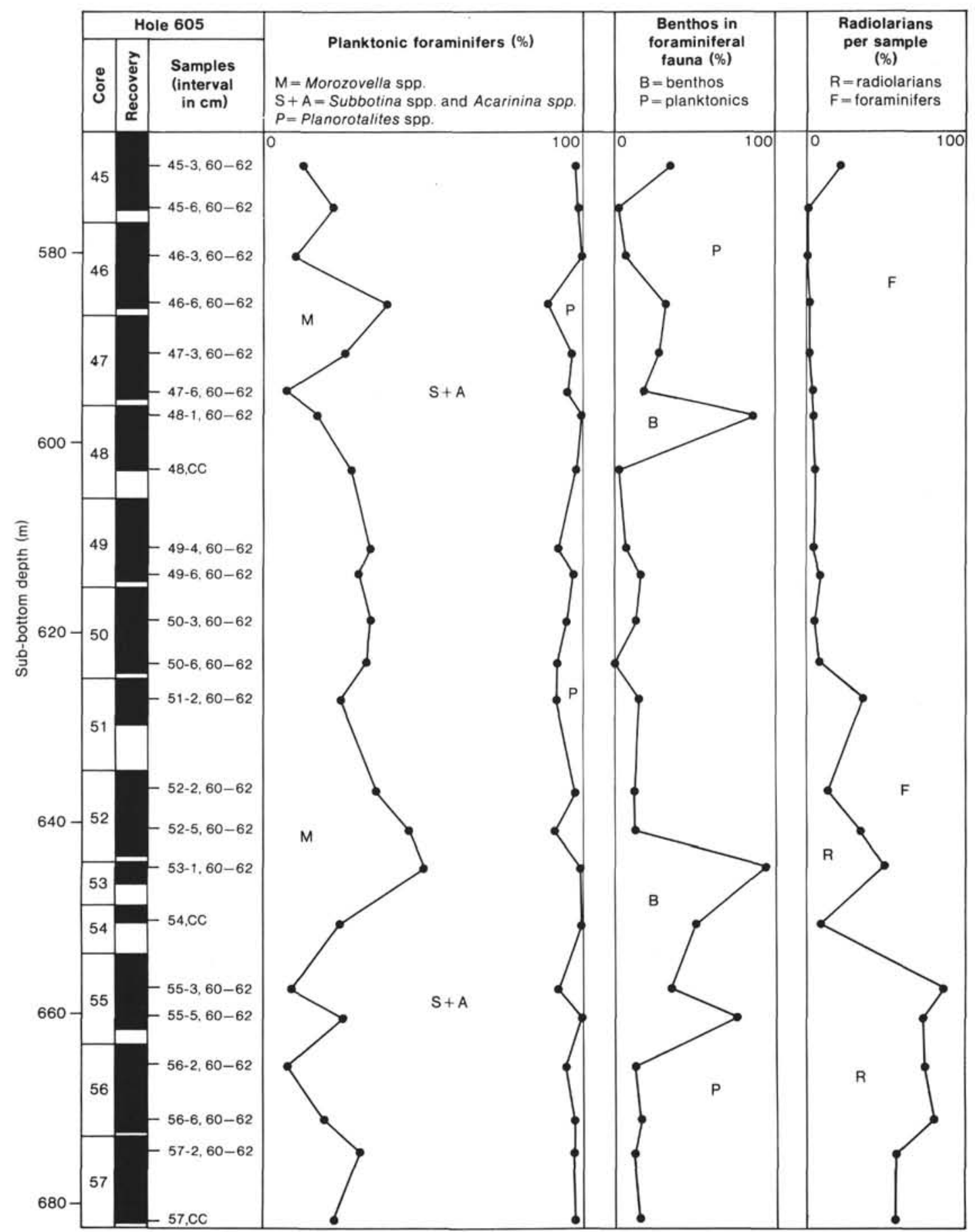

Figure 3. Relative abundances of planktonic foraminiferal genera, benthic foraminifers, and radiolarians in 23 samples from the upper Paleocene. The correlation between the abundances of Morozovella spp. and of Acarinina spp. and Subbotina spp. is highly negative, because their abundances add up to nearly $100 \%$. The correlation coefficients between all other curves are low, between -0.45 and +0.38 .

number is 4.0); (8) total number of chambers in the last whorl (the first chamber of the last whorl is counted as $0.25,0.5,0.75$, or 1.0 if, respectively, some, half, most, or all of this chamber is visible on the umbilical side-in Fig. 4B this number is 4.75); and (9) height of peripheral curvature of the penultimate chamber.

All nine variables can easily be measured accurately, even on slightly damaged specimens. Parameters 1 through 5 and 9 are simple measures of size; combinations of these variables describe test shape: the relation between 3 and 4 is a measure of increase in chamber size; 4 and 9 together are a measure of lobateness. A combination of 7 and 8 gives the proportion of keeled periphery. In a multivariate data analysis the importance of the variables relative to each other is established. Initially, test height and concavity were also measured on side views; test runs on specimens from two samples showed that the addition of these variables did not influence the results in any clear way, so their measurement was abandoned.

The relative proportions of radiolarians, benthic foraminifers, and the planktonic foraminiferal genera Morozovella, Subbotina and Acarinina, and Planorotalites were estimated in 23 of the shipboard samples (Fig. 3). These proportions all vary within the section, but they 
A

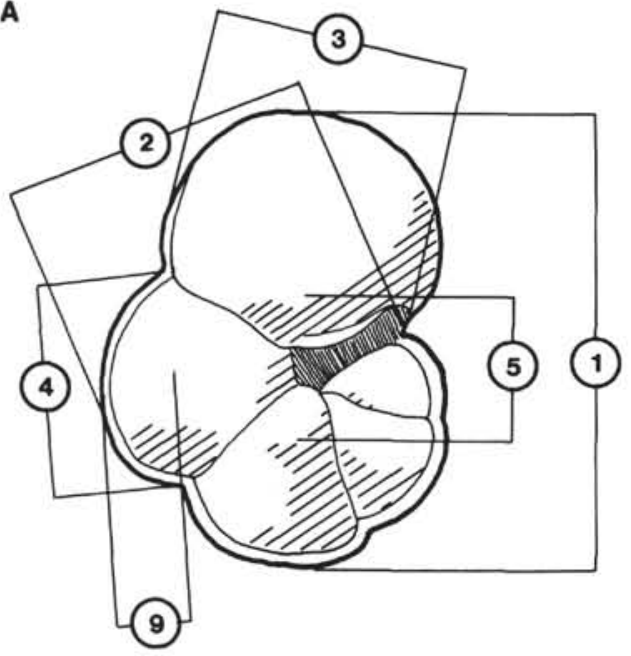

B

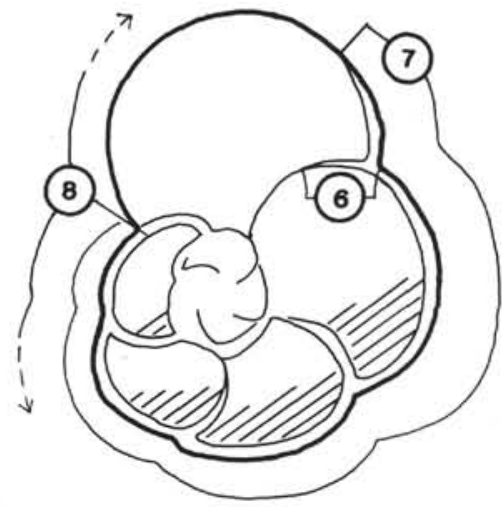

Figure 4. Line drawing of (A) umbilical and (B) dorsal sides of a Planorotalites test showing the nine variables that have been determined (see text). On the umbilical side: $1=$ total length; $2=$ total width; $3=$ base width of ultimate chamber; $4=$ width of penultimate chamber; $5=$ width of umbilicus (distance between shoulders) and $9=$ peripheral curvature of penultimate chamber. On the spiral side: $6=$ relative length of limbate suture ( $40 \%$ in this example); 7 = number of keeled chambers in the last whorl ( 4.0 in this example); and $8=$ total number of chambers in the last whorl (4.75 in this example).

are not clearly correlated with each other. If the abundance of benthic foraminifers in an assemblage is assumed to be a measure of carbonate dissolution, then it appears that the changing frequencies of the foraminiferal genera are at most partly the result of selective dissolution. The amount of radiolarians per sample also shows a low correlation with the percentage of benthos in the foraminiferal fauna (the correlation coefficient is 0.38 , which is not significant at a $95 \%$ level). It is likely that the presence of large amounts of radiolarians should be largely attributed to other processes than dissolution. We interpret these processes to be the result of environmental conditions-possibly low temperature or high nutrient content or both. Recent concentrations of radiolarians are known from areas with cool, nutrient-rich surface waters at high latitudes and in upwelling areas. One would not expect upwelling in the Tertiary western Atlantic; more probable is the presence of cool surface waters associated with the proto-Labrador current. Samples containing abundant benthic foraminifers were excluded from further analysis.

\section{ANALYSIS}

The nine variables that describe morphologic variation were measured on Planorotalites specimens from nine samples. From each of these samples a total of 25 to 46 specimens were selected, the number depending on the frequency of undamaged Planorotalites specimens within the samples.

Six of the samples are located well within the $P$. pseudomenardii Zone (Samples 605-53-1, 0-4 cm; 605-52-6, 60-62 cm; 605-50-6, 60-62 cm; 605-49-6, 60-62 cm; 60547-6, 60-62 cm; and 605-46-6, 60-62 cm). These six samples are not equally spaced throughout the $P$. pseudomenardii Zone; most samples from the lower part of the section could not be included, because they contain only rare Planorotalites specimens. The three other samples from which specimens have been measured cover the exit of $P$. pseudomenardii: shipboard Sample 605-46-3, 60$62 \mathrm{~cm}$ is the first sample in which $P$. pseudomenardii is not present; Samples 605-46-4, 95-99 cm and 605-46-4, $5-9 \mathrm{~cm}$ are from a $1.5-\mathrm{m}$-thick sequence immediately below the exit, in which the Planorotalites faunas appear to be less well developed than in the older sedi- ments. The nine samples together sufficiently show morphologic trends and variation of Planorotalites through the covered section.

To evaluate conventional taxonomic practice, all specimens of Planorotalites were assigned to one of four morphologic categories using the traditional criteria, which qualitatively describe variation within $P$. pseudomenardii and between P. pseudomenardii and other Planorotalites forms. Category 1 consists of all unkeeled specimens. Category 2 specimens have a keel or keel-like feature along some, but not all, chambers of the last whorl. Specimens in categories 3 and 4 are completely keeled; those in category 3 have depressed sutures on the spiral side, those in category 4 have limbate or flush sutures. (These four categories are visible in Fig. 6, later.) Clearly, the presence or absence of a keel is an important characteristic. Other shape variables that have been used in previous descriptions of morphologic differences both within $P$. pseudomenardii and between $P$. pseudomenardii and unkeeled Planorotalites proved to be unimportant.

Quantitative analysis based upon the nine morphologic variables established earlier leads to the conclusion that in fact only two, not four, forms can be distinguished within Planorotalites: one is keeled, the other unkeeled. A (weighted-pair group) cluster analysis was carried out on all nine samples separately. The resulting clustering for Sample 605-46-6, 60-62 cm, a sample within the main part of the P. pseudomenardii Zone, is shown in Figure 5. The other samples give comparable results. The specimens cluster into two large groups, one consisting of all completely keeled Planorotalites specimens, which we assign to $P$. pseudomenardii, the other containing all unkeeled and partially keeled specimens. Within P. pseudomenardii there are two subclusters: the larger subcluster consists of all specimens with limbate sutures on the spiral side; the smaller one represents those with (partially) depressed sutures. Subclusters within the 


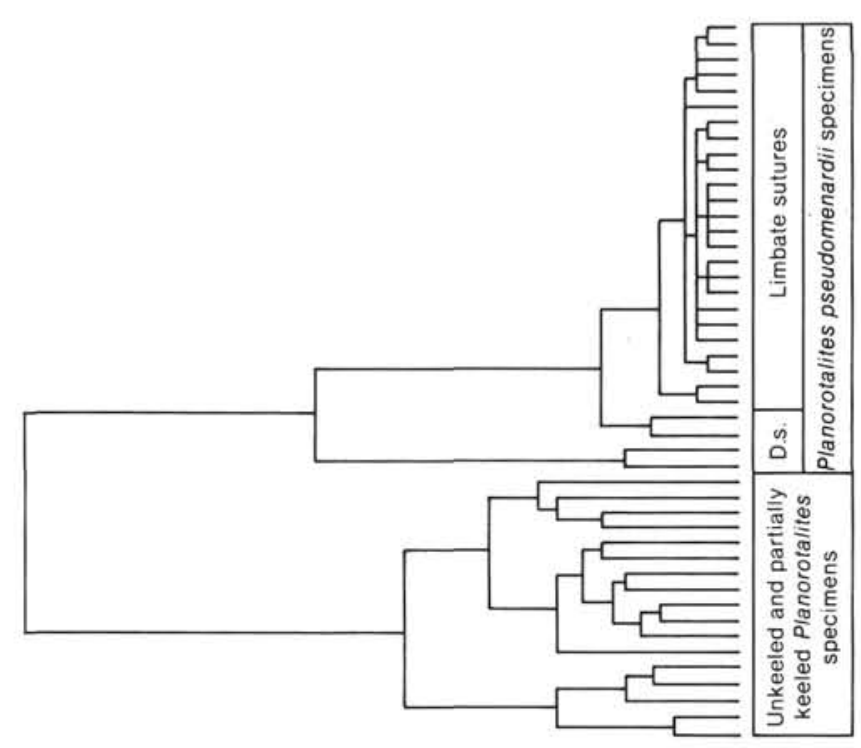

Figure 5. Dendrogram of weighted-pair group clustering on distances between measurements of 46 specimens from Sample 605-46-6, 60$62 \mathrm{~cm}$. The subclusters within the unkeeled Planorotalites do not coincide with forms described in the literature. Correlation between the clusters of the keeled and the unkeeled Planorotalites specimens is close to zero (D.s. $=$ depressed sutures).

second main cluster, that of unkeeled Planorotalites specimens, cannot be related to any specific category or "species."

To further test polymorphism within this genus, a principal-component analysis was carried out on the measurements of specimens from all nine samples together using the nine morphologic variables listed in the Methods section. The measurements were standardized to avoid undue influence from those variables that give large numerical values (e.g., length $=300 \mu \mathrm{m}$, number of chambers in the last whorl $=5.25$ ). The first three principal components together represent $91 \%$ of the variance within the total data set. The first principal component explains $56 \%$ of the variance and is mostly dependent on all size variables (variables $1-5,9)$ equally; the other variables influence it only slightly. The second component explains $24 \%$ of the variance and depends mainly on the presence or absence of a keel and of limbate sutures on the spiral side (variables 6 and 7). The third principal component explains another $11 \%$ and is almost completely dependent on the number of chambers in the last whorl (variable 8).

As did the cluster analysis, so do the loadings of the standardized measurements on the first two principal components indicate a clear separation between all keeled specimens ( $P$. pseudomenardii) and all unkeeled or partially keeled Planorotalites specimens (Fig. 6). The best separation is along a straight line, with $96 \%$ of all keeled specimens on one side of this line, and $96 \%$ of all unkeeled and partially keeled specimens on the other side. This line of division makes an angle with both the first and the second principal component; neither of the two principal components alone is sufficient to give an optimal division among the keeled and unkeeled Planorotalites specimens.
Figure 7A illustrates that a combination of the second principal component (keel) and the third (number of chambers) subdivides the keeled and unkeeled specimens only to some extent. Along the third principal component, some unkeeled Planorotalites specimens can be separated according to the number of chambers in the last whorl-a feature that in the literature has been used as a defining characteristic for some species (Fig. 7B). For instances, $P$. chapmani s.s. is supposed to have 4 to 6 chambers in the last whorl; the so-called " $P$. ehrenbergi," " $P$. hausbergensis," and " $P$. planoconica" (all of which we assign to P. chapmani; see Taxonomic note, later) have 4.5 to 6 . In the Figure 7 diagrams, however, the fields covered by these species all overlap. Of other such species, the so-called " $P$. imitata" is supposed to have 4 to 4.5 chambers in the last whorl, " $P$. troelseni" 5 or more. Along the third principal component the loadings of specimens from these last two forms have mutually exclusive ranges, but both also overlap completely with one or more of the other four unkeeled forms.

The differentiation of $P$. pseudomenardii into two categories, one with depressed, the other with limbate sutures on the spiral side was intended to reflect the differences between Bolli's (1957) type specimens and the hypotypes that Loeblich and Tappan (1957) assigned, respectively. At first sight this difference seems to be considerable, and is reproduced by clustering. However, the difference between depressed and limbature sutures is minor, if compared to the distinction between keeled and unkeeled specimens. Moreover, the first and second principal component together reproduce the subdivision between keeled ( $P$. pseudomenardii) and unkeeled (other Planorotalites) very clearly, and none of the other variables influences that subdivision.

The results of the principal-component analysis, and the changing relative abundances of all qualitatively distinguished Planorotalites forms give an overview of the morphologic variations of Planorotalites in the P. pseudomenardii Zone. In the lower part of the P. pseudomenardii Zone the abundance of $P$. pseudomenardii relative to the unkeeled forms increases irregularly (Fig. 8). In the upper part, these abundances vary only slightly around $65 \%$. Changes in these abundances show a very strong negative correlation with the amount of radiolarians in each of the samples (correlation coefficient = -0.96 , which appears to be too high to be solely the result of selective dissolution). Among the unkeeled forms, the abundances of " $P$. ehrenbergi" and of $P$. chapmani s.s. specimens also correlate to some extent to the amount of radiolarians present in the samples (correlation coefficient with " $P$. ehrenbergi" $=0.70$, with $P$. chapmani s.s. $=-0.53)$. The other unkeeled forms, "P. imitata," " $P$. hausbergenis," "P. planoconica," and " $P$ troelseni," are, however, too erratically distributed to show any definite trends. If we add their abundances to either " $P$. ehrenbergi" or $P$. chapmani s.s., it appears that the numbers of Planorotalites specimens with an acute periphery (" $P$. ehrenbergi" and " $P$. hausbergensis") decrease with the numbers of radiolarians (correlation coefficient $=0.71$ ), in contrast to the abundance of the other forms with a more rounded periphery (correlation coefficient 




Figure 6. Plot of loadings of standardized data on the first and second principal components (P.C.) of variation in Planorotalites determined by nine variables (Fig. 4). The first principal component explains $56 \%$ of the variation in the total data set; the second, $24 \%$. These two principal components together divide all specimens into two groups, keeled (P. pseudomenardii) and unkeeled or partially keeled. The dotted line of division gives the best separation between the two groups, with only $4 \%$ ( 7 specimens) of both groups on the opposing side of the line. The inset shows the stratigraphic position of the nine samples used for the principal-component analysis. The legend distinguishes the four morphologic categories to which all specimens have been assigned.

$=-0.70$ ). However, none of the forms is confined to any specific part of the section.

For each sample included in the principal-component analysis, the same loadings on the first and second principal component as in Figure 6 were plotted separately, to show possible variation among samples (Fig. 9). The same line can be drawn as in Figure 6, dividing the keeled and the unkeeled specimens.

In Figure 9, also, the diagrams of the six samples that are located well within the $P$. pseudomenardii Zone each show approximately the same configuration, indicating that the overall morphology of both Planorotalites groups remained the same throughout the section. However, these results should be treated with some reservations, because the principal-component analysis covers an incomplete record of the zone. These six samples were chosen from those that contain only minor amounts of radiolarians, because samples with high radiolarian frequencies contain insufficient Planorotalites specimens to be analyzed. One might find changes in the morphology of Planorotalites if larger samples were taken in the Planorotalitespoor intervals.

In the samples situated directly below the exit of $P$. pseudomenardii (605-46-4, 95-99 cm and 605-46-4, 5-9 $\mathrm{cm}$ ), the loadings on the first and second principal components show a different distribution (Fig. 9), with the unkeeled Planorotalites specimens being mostly confined to the left side of the diagram. Of the partially keeled specimens in Sample 605-46-4, 95-99 cm, three of seven in all samples plot below the line of division. In Sample $605-46-4,5-9 \mathrm{~cm}$ P. pseudomenardii is also confined to the left side of the diagram: specimens plot close to the line of division, with six specimens above this line in the "unkeeled" region. In these two samples (and in the samples between), Planorotalites specimens have become smaller than in the older samples (Fig. 10), which explains most of the anomalous configurations along the first and second principal components. Both are from a 1.5 -m-thick sequence (starting at $605-46-4,95-99 \mathrm{~cm}$ ) in which the proportion of $P$. pseudomenardii relative to the unkeeled forms decreases (Fig. 8). This proportion has become zero in shipboard Sample 605-46-3, 60-62 $\mathrm{cm}$, the first sample in the upper Paleocene Morozovella velascoensis Zone. The loadings of the Planorotalites specimens from this sample again show approximately the same distributional range along the first two principal components as the unkeeled specimens in the older samples (Fig. 9).

\section{DISCUSSION}

The exact position of the entry of $P$. pseudomenardii at Site 605 cannot be established, because it is located within a part of the section with an erratic Planorotalites distribution and low P. pseudomenardii abundances. 
A

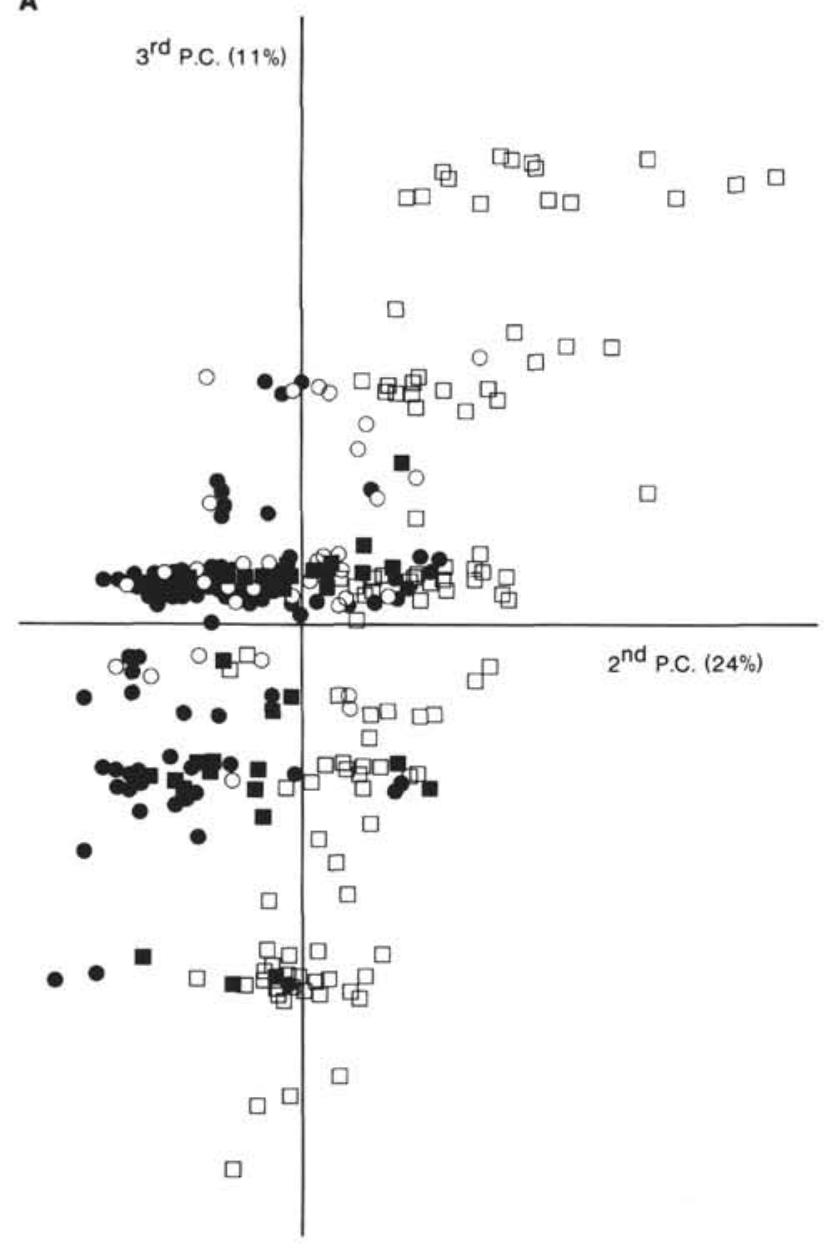

B

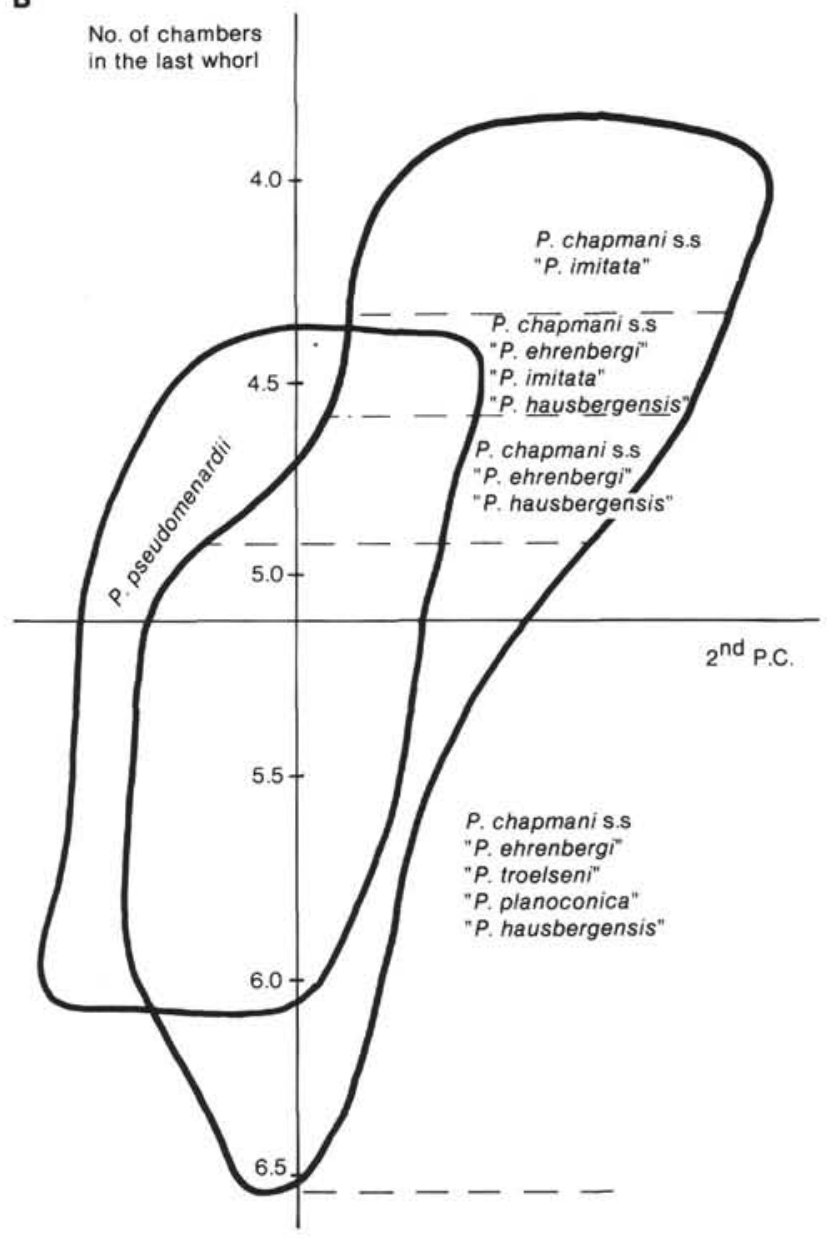

Figure 7. A. Plot of loadings on the second and third principal components (P.C.) of variation in Planorotalites based on nine variables (Fig. 4). The second principal component explains $24 \%$ of the variation in the total data set; the third, $11 \%$. B. Contours around the fields occupied by all keeled and by all unkeeled or partially keeled specimens as in Figure 7A. The third principal component has been translated into scale units denoting the number of chambers in the last whorl. It is also shown in which parts of the unkeeled field different Planorotalites forms plot. (See Fig. 6 for legend and sample position.)

The approximate position can be estimated: $605-56-2$, $60-62 \mathrm{~cm}$ is the lowest sample containing $P$. pseudomenardii. In Sample 56,CC, 25 unkeeled Planorotalites specimens were found, whereas the number of radiolarians in this sample is relatively low- $25 \%$. Assuming that the high negative correlation between $P$. pseudomenardii and radiolarians still holds in this part of the section, at least some $P$. pseudomenardii specimens would be expected in a total of 25 Planorotalites, if this sample were part of the P. pseudomenardii Zone. We therefore expect the entry of $P$. pseudomenardii to be situated between these two samples.

Morphologically, the few $P$. pseudomenardii specimens found in 605-56-2, 60-62 cm appear to fall in the range of variation exhibited in the samples higher in the section. Assuming that the entry of $P$. pseudomenardii at Site 605 is not the result of geographical migration, this would indicate a rather rapid development, followed by a much longer period or morphologic stability. Such results have been found in studies of the entries of other planktonic foraminiferal species (Malmgren et al., 1983; Jansen et al., 1984). The negative correlation with the number of radiolarians suggests that the entry, and the slow increase in the abundance of $P$. pseudomenardii during the first third of its range at Site 605 , could be the result of environmental changes (or differential dissolution), rather than evolutionary processes.

Judging by the samples studied here, the relative abundance of keeled and unkeeled specimens within the genus Planorotalites appears to be a clear paleoecologic indicator. This ratio might be temperature dependent; this possibility could not be checked with stable isotope measurements $\left(\delta^{18} \mathrm{O}\right)$, for the specimens are mostly filled with calcite. Because no time-consistent morphological changes have been found, it appears unlikely that the $P$. pseudomenardii Zone can be subdivided into biostratigraphic units using the genus Planorotalites.

Although different unkeeled Planorotalites forms described in the literature have been qualitatively distinguished as species, their differences are not clearly reproduced in the principal component and cluster analyses. The variation within $P$. pseudomenardii is nearly of the same order as the variation within the unkeeled Planorotalites forms. All these unkeeled forms are found 


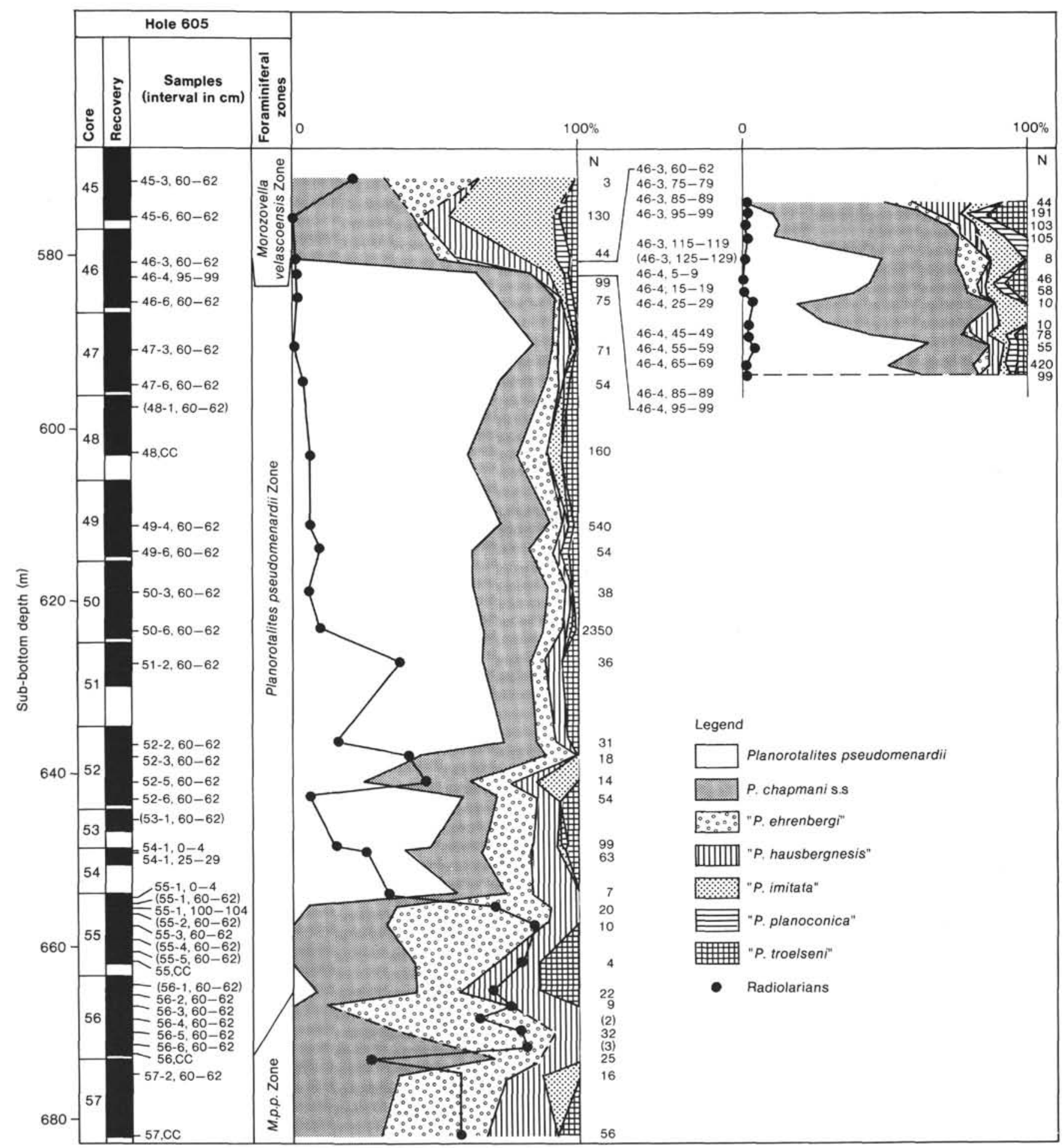

Figure 8. Diagram showing relative abundances (in \%) of Planorotalites species in 49 samples from the upper Paleocene at Site 605 and the percentages of radiolarians in the total faunas of these samples. Outlay shows detail of the $1.5 \mathrm{~m}$ of section preceding the exit of $P$. pseudomenardii. Samples containing no Planorotalites are in parentheses. M.p.p. Zone $=$ Morozovella pusilla pusilla Zone. $\mathrm{N}=$ number of Planorotalites specimens found in the samples; $\mathrm{N}$ in parentheses indicates that sample was used in calculating radiolarian percentages only.

throughout the section (Morozovella pusilla pusilla Zone to Morozovella velascoensis Zone), though relative proportions vary, apparently in correlation with the changing proportion of keeled/unkeeled Planorotalites.

Distinguishing more than one unkeeled species does not give any added stratigraphic information; any possi- ble paleoecologic information is most clearly present in the changing abundances of $P$. pseudomenardii. For these reasons we prefer to recognize only one unkeeled species, Planorotalites chapmani (Parr), which ranges from the middle Paleocene to at least the top of the Paleocene; and we consider $P$. ehrenbergi, $P$. imitata, $P$. plano- 

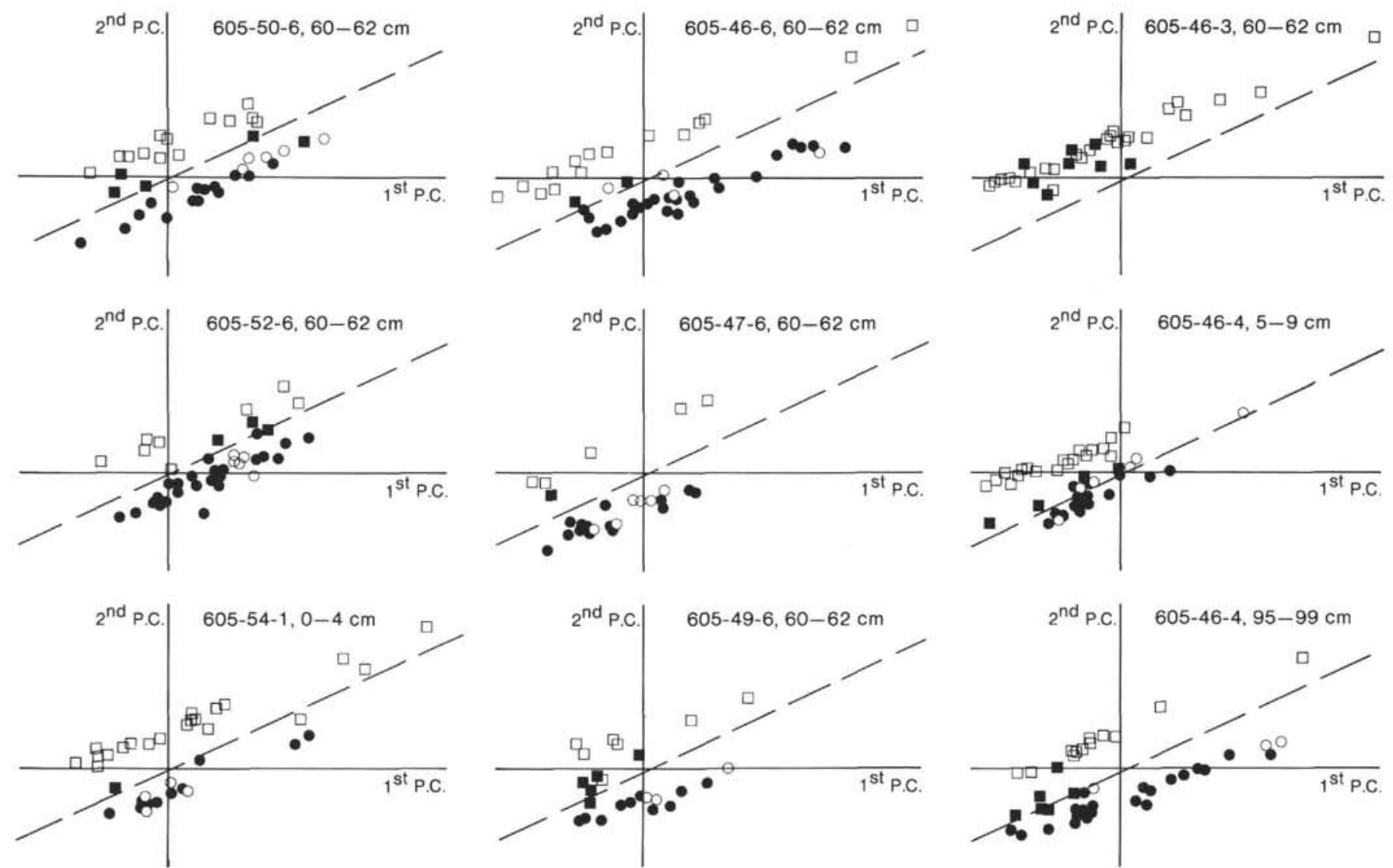

Figure 9. Plots of loadings of standardized data on first and second principal components for each of nine samples separately. Comparison of the plots visually shows the variation between Planorotalites faunas in different samples. Note the anomalous distribution in Samples 605-46-4, 95$99 \mathrm{~cm}$ and $605-46-4,5-9 \mathrm{~cm}$ discussed in the text. For sample position and legend see Figure 6.

conica, P. troelseni, and P. hausbergensis as junior synonyms (see Taxonomic Notes on P. chapmani, later).

The exit of $P$. pseudomenardii seems to be the result of some process that affected both $P$. pseudomenardii and the unkeeled Planorotalites. Specimens from both these groups show a decrease in size in the $1.5 \mathrm{~m}$ of sediments preceding the exit of $P$. pseudomenardii. These sediments represent an estimated period of 40,000 years, assuming sediment accumulation rates of $4 \mathrm{~cm} / 10^{3}$ years. Possibly some kind of environmental "bottleneck" was created, which finally resulted in the exit of $P$. pseudomenardii, after a slow decline in frequencies relative to $P$. chapmani. The absolute numbers of Planorotalites specimens in the middle part of this 1.5 -m-thick sequence are lower than in the surrounding samples. In this case these low numbers do not coincide with an increase in the radiolarian content of these samples. Furthermore, the foraminiferal faunas in this part of the sequence are among the best preserved in all of the section (preservation is at least partially dependent on environmental factors). This all seems to indicate that the changing frequencies are real, probably reflecting a change in environment.

The exit of P. pseudomenardii at Site 605 is found in Magnetozone C24R (Bruins et al., this volume), and appears to be younger than would be expected from current standard biochronologies. In recent time scales (Vail and Mitchum, 1979; Berggren et al., 1985) the top of the P. pseudomenardii Range Zone is placed in the older Magnetozone $\mathrm{C} 25 \mathrm{~N}$. One explanation could be that the magnetostratigraphic correlation should be revised. However, it is also possible that the young magnetic age found for the exit of $P$. pseudomenardii indicates that the top of the $P$. pseudomenardii Zone is diachronous.

\section{TAXONOMIC NOTES ON PLANOROTALITES}

\section{PLANOROTALITES Morozova, 1957}

Planorotalites chapmani (Parr) 1938

(Plate 2, Figs. 1-16, Plate 3, Figs. 1-15)

\section{Synonymy}

Globorotalia chapmani Parr, 1938, pl. 3, figs. 8, 9a, b.

Globorotalia imitata Subbotina, 1953, pl. 16, figs. 14a-16c; Loeblich and Tappan, 1957, pl. 44, fig. 3a-c; pl. 45, fig. 6a-c; pl. 59, fig. $5 \mathrm{a}-\mathrm{c} ;$ pl. 63 , fig. $3 \mathrm{a}-\mathrm{c}$.

Globorotalia planoconica Subbotina, 1953, pl. 17, figs. 4a-6c.

Globorotalia ehrenbergi Bolli, 1957, pl. 20, figs. 18-20.

Globorotalia elongata, Bolli, 1957 (non Glaessner), pl. 20, figs. 11-13; Loeblich and Tappan, 1957 (non Glaessner), pl. 45, fig. 5a-c; pl. 146 , fig. $5 a-c ;$ pl. 48 , fig. $5 a-c ;$ pl. 49 , fig. $7 a-c ;$ pl. 54 , figs. $1-5$; pl. 59 , fig. $4 a-c ;$ pl. 60 , fig. 9 a-c; pl. 63 , fig. $2 a-c$.

Globorotalia pseudomenardii, Loeblich and Tappan (non Bolli), 1957, pl. 45, fig. 10a-c; pl. 59, fig. 3a-c; Blow (non Bolli), 1979, pl. 105, figs. 3, 7-10; pl. 111, figs. 1-4; pl. 112, figs. 2, 3, 9, 10 .

Globorotalia troelseni Loeblich and Tappan, 1957, pl. 60, fig. 4a-c; pl. 63 , fig. 5a-c.; Blow, 1979, pl. 89, figs. 6-10; pl. 90, figs. 1, 2; pl. 234 , figs. 1-6.

Globorotalia hausbergensis Gohrbrandt, 1963, pl. 6, figs. 10-12.; Blow, 1979 , pl. 88, figs. $6,8,9$. 


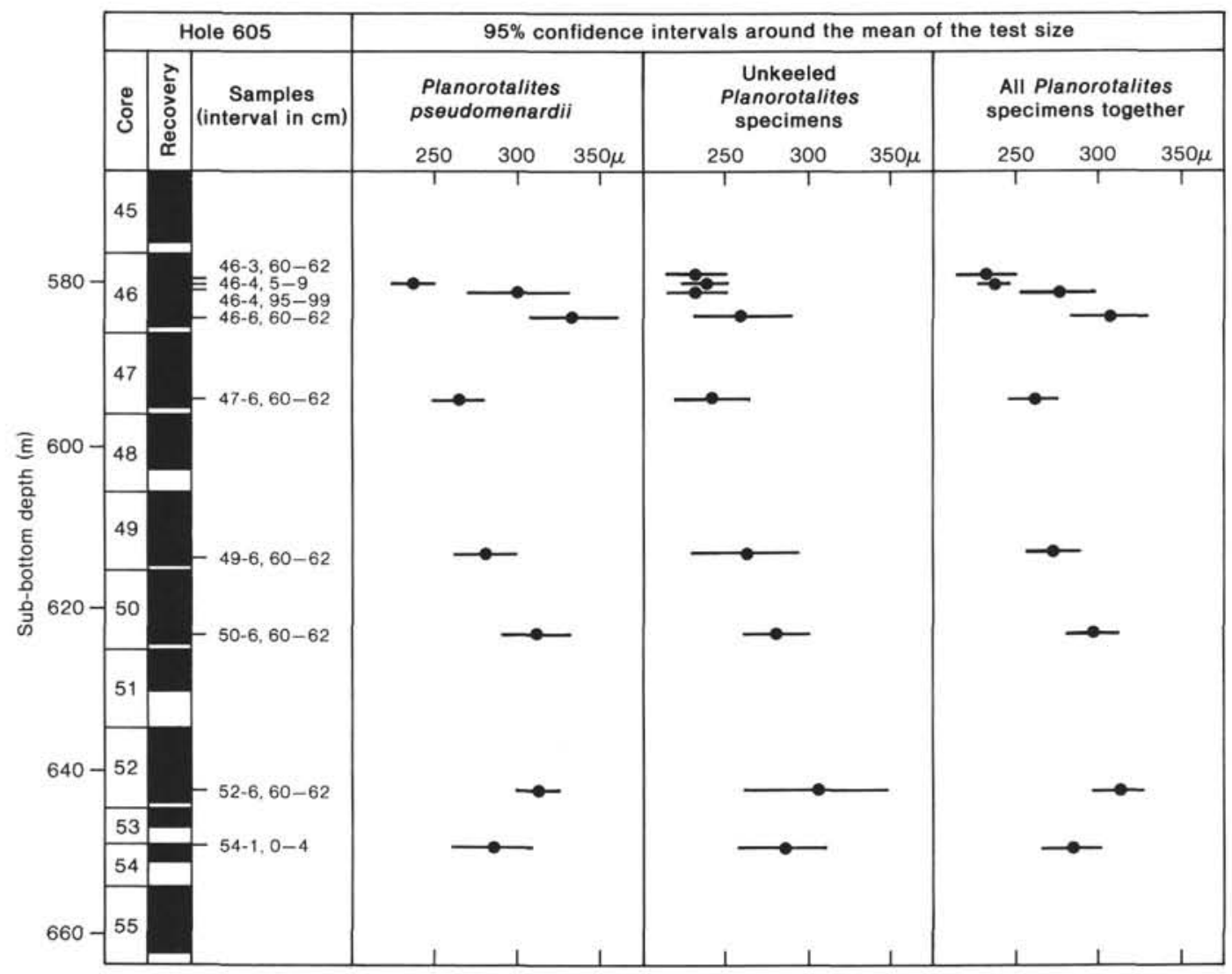

Figure 10. Mean test diameter (dots) and $95 \%$ confidence intervals around the mean test diameter (bars) of $P$. pseudomenardii, unkeeled Planorotalites, and all Planorotalites specimens together in the nine samples included in the principal-component analysis.

\section{Remarks}

Planorotalites chapmani is an unkeeled, or at most partially keeled Planorotalites species, which consists of a variety of forms that have been distinguished as separate species by various authors. Planorotalites imitata is supposed to differ from $P$. chapmani in having four chambers in the last whorl and a flattened spiral side; $P$. planoconica in having five or more chambers in the last whorl, a flattened spiral side, and an acute periphery. $P$. ehrenbergi should differ from $P$. chapmani in having a plano-convex test and a more acute periphery, with a pseudo-keel. This species is described as having its exit halfway through the Planorotalites pseudomenardii Zone, but at Site 605 this form has also been found in the upper part of the $P$. pseudomenardii Zone and in the younger Morozovella velascoensis Zone. Forms having a tendency to uncoil, showing part of the previous whorls at the umbilical side, have been described as $P$. troelseni. $P$. hausbergensis is supposed to differ from $P$. chapmani in having a more acute periphery and less clearly depressed sutures, curving backwards, on the spiral side.

Globorotalia pseudoscitula var. elongata Glaessner (1937) is a keeled Eocene form; the name Globorotalia elongata erroneously has been applied to unkeeled upper Paleocene forms by Bolli (1957) and Loeblich and Tappan (1957).

The characteristics distinguishing these forms show up in different combinations of the measurements of the variables described in the above text. The flattened spiral side of $P$. imitata and $P$. planoconica combines with a larger distance between umbilical shoulders than in plano-convex specimens; the test of the uncoiling $P$. troelseni is more elongate than those of other specimens. As mentioned above, these characteristics cannot be used to quantitatively distinguish groups within the unkeeled Planorotalites, except for, to some extent only, the number of chambers in the last whorl. Neither does the relative frequency of the different morphotypes show variation that could be of stratigraphic use. Within the $P$. pseudomenardii Zone any paleoecologic information incorporated in their relative frequencies is more clearly represented in the relative frequency of $P$. pseudomenardii.
The test of $P$. chapmani is finely perforate. The pores in specimens from Site 605 are usually concentrated on the peripheral half of the chambers, except for an imperforate band along the periphery of the first few, or all, chambers of the last whorl. The imperforate band may be slightly thickened at the first two or three chambers of the last whorl to form the onset of a keel. Such specimens, which appear to be transitional to $P$. pseudomenardii, occur throughout the section. $P$. chapmani was originally described as an upper Eocene species (Parr, 1938), but later McGowran (1964) showed that its type level is of late Paleocene age, within P. pseudomenardii Zone. McGowran (1964) also noted that $P$. chapmani has an imperforate band along its periphery. $P$. chapmani differs from $P$. pseudomenardii in having two or more unkeeled chambers.

Most of the specimens depicted in Plates 2 and 3 are from Sample $605-46-4,85-89 \mathrm{~cm}$, near the base of the $1.5-\mathrm{m}$ section preceding the exit of $P$. pseudomenardii. This is the only sample containing well preserved $P$. chapmani in sufficient numbers to show the complete range of variation in this group. Whereas the mean size of $P$. chapmani in this sample is smaller than in lower samples, we believe that the figured specimens are representative as far as shape is concerned.

\section{Planorotalites pseudomenardii Bolli, 1957} (Plate 1, Figs. 1-16)

\section{Synonymy}

Globorotalia pseudomenardii Bolli, 1957, pl. 20, figs. 14-17; Loeblich and Tappan, 1957, pl. 47, fig. 4a-c; pl. 49, fig. 6a-c; pl. 54, fig. $3 a-c ;$ pl. 60, fig. 1a-c (non pl. 45, fig. 10a-c, pl. 59, fig. 3a-c); Blow, 1979, pl. 89 , figs. $1-5$; pl. 94 , figs. $1-5$; pl. 108 , figs. $4-7$ (non pl. 105, figs. 3, 7-10; pl. 111, figs. 1-4; pl. 112, figs. 2, 3, 9, $10)$.

\section{Remarks}

This is a keeled species of Planorotalites in which the ultimate chamber may lack a keel. The umbilical shoulders are closely spaced around 
the umbilicus. The chambers increase fairly rapidly in size and the test of full-grown specimens is clearly lobate. P. pseudomenardii has between 4.5 and 5.5 but usually 5 chambers in the last whorl. Maximum test size is $350 \mu \mathrm{m}$; average test size is around $250 \mu \mathrm{m}$. P. pseudomenardii is finely perforate. As is illustrated in Plate 1, the pores in most specimens are concentrated along the outer half of the chambers and sutures, leaving imperforate shoulders on the umbilical side.

Forms like the hypotypes given by Loeblich and Tappan, 1957, are abundant in Hole 605; they differ from Bolli's holo- and paratype in having limbate sutures on the spiral side. Morphotypes resembling the small holotype (Bolli, 1957, plate 20, figs. 14-16) are absent at Site 605 ; those resembling the larger paratype (Bolli, 1957, plate 20, fig. 17) are relatively rare. Forms transitional to $P$. pseudomenardii sensu Loeblich and Tappan have been found, having half limbate, half depressed sutures on the spiral side.

Blow (1979) argued that $P$. pseudomenardii sensu Bolli and $P$. pseudomenardii sensu Loeblich and Tappan are distinct, though he did not give different species names. $P$. pseudomenardii sensu Loeblich and Tappan would have a longer range. Blow illustrated an Eocene form that indeed closely resembles $P$. pseudomenardii. However, in our opinion the Eocene forms are homologues, and are related to Planorotalites pseudoscitula (Glaessner) s.1. Blow (1979) also depicted small forms from the Morozovella velascoensis Zone as $P$. pseudomenardii; these do not have a distinct keel and should be included in $P$. chapmani.

At Site $605 P$. chapmani specimens have been found that resemble P. pseudomenardii in general shape; they are much smaller, however, and have an imperforate periphery but not a keel. These forms are found in the $P$. pseudomenardii Zone as well as in the $M$. velascoensis Zone. Just prior to the decline of $P$. pseudomenardii these forms are difficult to distinguish from $P$. pseudomenardii, because the overall size of $P$. pseudomenardii specimens decreases.

Throughout its range $P$. pseudomenardii occurs with $P$. chapmani, from which it differs in having a keeled or partly keeled last chamber.

\section{ACKNOWLEDGMENTS}

Thanks are due to the shipboard scientific party and technicians of Glomar Challenger's DSDP Leg 93 for making the material available and the DSDP office for additional onshore sampling. We thank Saskia Kars (V.U., Amsterdam) for producing the SEM photographs and Ynze A. Baumfalk (V.U., Amsterdam) for discussions on the results of the data analyses.

\section{REFERENCES}

Berggren, W. A., 1977. Atlas of Paleogene Planktonic Foraminifera; some species of the genera Subbotina, Planorotalites, Morozovella, Acarinina and Truncatulinoides. Oceanic Micropaleontol., 1: 205-265.
Berggren, W. A., Kent, D. V., Flynn, J. J., and Van Couvering, J. A., 1985. Cenozoic geochronology. Geol. Soc. Am. Bull., 96:14071418.

Blow, W. H., 1979. The Cainozoic Globigerinida, a Study of the Morphology, Taxonomy, Evolutionary Relationships and Stratigraphical Distribution of Some Globigerinida (mainly Globigerinacea): Leiden (E. J. Brill).

Bolli, H. M., 1957. The genera Globigerina and Globorotalia in the Paleocene-Lower Eocene Lizard Springs Formation of Trinidad, B.W.I. U.S. Nat. Mus. Bull., 215:61-81.

Glaessner, M. F., 1937. Planktonforaminiferen aus der Kreide und der Eozän und ihre stratigraphische Bedeutung. Studies Micropaleontol. Publ. Lab. Paleontol. Moscow Univ., 1:27-46.

Gorhbrandt, K., 1963. Zur Gliederung des Palaeogen im Helvetikum, oerdlich Salzburg nach planktonischen Foraminiferen. Mitt. Geol. Ges. Wien, 56:1-116.

Jansen, H., Kroon, D., and van Hinte, J. E., 1984. Entry and exit of Planomalina buxtorfi in a section north of Velez Blanco, S. E. Spain. Rev. Esp. Micropaleontol., 16:381-397.

Loeblich, A. R., and Tappan, H., 1957. Planktonic foraminifers of the Paleocene and early Eocene from the Gulf and Atlantic Coastal Plains. U.S. Nat. Mus. Bull., 215:173-197.

McGowran, B., 1964. Foraminiferal evidence for the Paleocene age of King's Park Shale (Perth Basin, Western Australia). R. Soc. Western Australia J., 47:81-88.

Malmgren, B. A., Berggren, W. A., and Lohmann, G. P., 1983. Evidence for punctuated gradualism in the Late Neogene Globorotalia tumida lineage of planktonic foraminifera. Paleobiology, 9:377-389.

Morozova, V. G., 1957. Foraminiferal superfamily Globigerinidae, superfam. nov., and some of its representatives. Akad. Nauk. S.S.S.R., Doklady, Moscow, 114:1109-1111. (Text in Russian.)

Parr, W. J., 1938. Upper Eocene Foraminifera from the deep borings in King's Park, Perth, Western Australia. R. Soc. Western Australia J., 24:69-101.

Postuma, J. A., 1971. Manual of Planktonic Foraminifera: Amsterdam (Elsevier).

Stainforth, R. M., Lamb, J. L., Luterbacher, H., Beard, J. H., and Jeffords, R. M., 1975. Cenozoic planktonic foraminiferal zonation and characteristics of index forms. Univ. Kansas Paleontol. Contrib., 62.

Subbotina, N. N., 1953. Globigerinidae, Hantkenindae, and Globorotalidae, fossil Foraminifera of the U.S.S.R. Vses. Neft. Nauchno Issled. Geol. Razved Inst. Trudy, 76. (Text in Russian.)

Vail, P. R., and Mitchum, R. M., 1979. Global cycles of relative changes of sea-level from seismic stratigraphy. Am. Assoc. Pet. Geol. Mem., 29:469-472.

Date of Initial Receipt: 2 May 1985

Date of Acceptance: 13 June 1986 


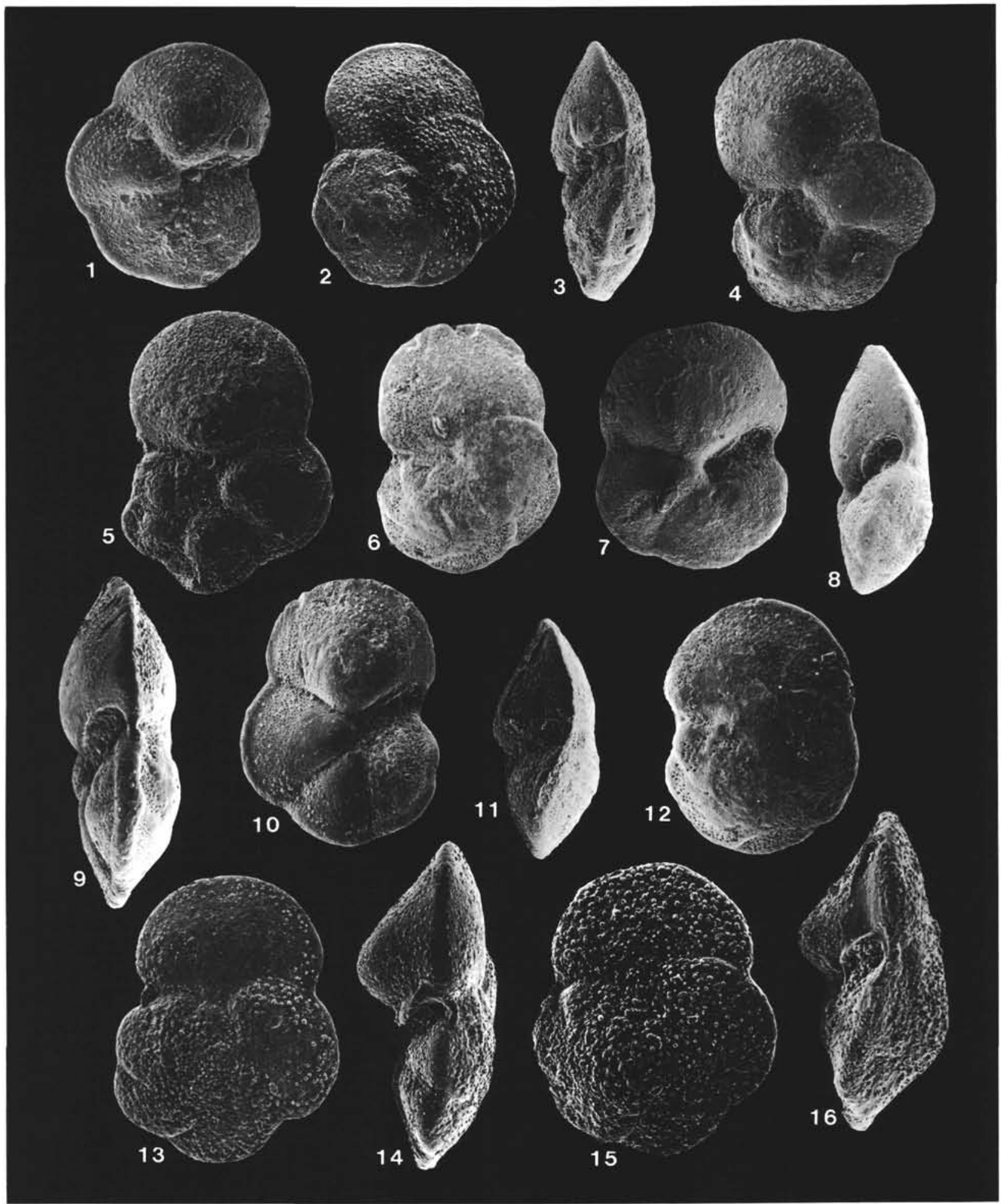

Plate 1. Planorotalites pseudomenardii. 1, 2, 3. Umbilical side (1), spiral side (2), and side view (3) of specimen with half limbate, half flush sutures on the spiral side. Sample 605-46-4, 95-99 cm; $\times 120$. 4. Spiral side of specimen with half limbate, half depressed sutures. Sample 605-46$6,60-62 \mathrm{~cm} ; \times 90$. 5. Spiral side of specimen with deeply depressed sutures on the spiral side, resembling Bolli's paratype. Sample 605-52-2, $60-62 \mathrm{~cm} ; \times 125$. 6. Spiral side of specimen with limbate sutures. Sample $605-46-4,85-89 \mathrm{~cm} ; \times 120$. 7, 8. Umbilical side (7) and side view (8) of specimen with low, broad chambers. Sample 605-46-4, 85-89 cm; $\times 120$. 9. Side view of plano-convex specimen. Sample 605-46-6, 60-62 cm; $\times 125$. 10. Umbilical side of specimen with onset of surface ornamentation on first two chambers of the last whorl. Sample 605-47-3, 60-62 cm; $\times 110$. 11. Side view of compact, probably nonadult specimen. Sample $605-46-6,60-62 \mathrm{~cm} ; \times 120$. 12. Spiral side of compact, probably nonadult specimen with rounded outline. Sample $605-46-6,60-62 \mathrm{~cm} ; \times 140,13,14$. Spiral side $(13)$ and side view (14) of specimen from the 1.5-m section preceding the exit of $P$. pseudomenardii. Note thin keel and small size. Sample $605-46-4,55-59 \mathrm{~cm} ; \times 200$. 15, 16. Spiral side $(15)$ and side view (16) of specimen from the 1.5 -m section preceding the exit of $P$. pseudomenardii. Note small size and thin keel. Sample 605-46-4, 5-9 cm; $\times 240$. 


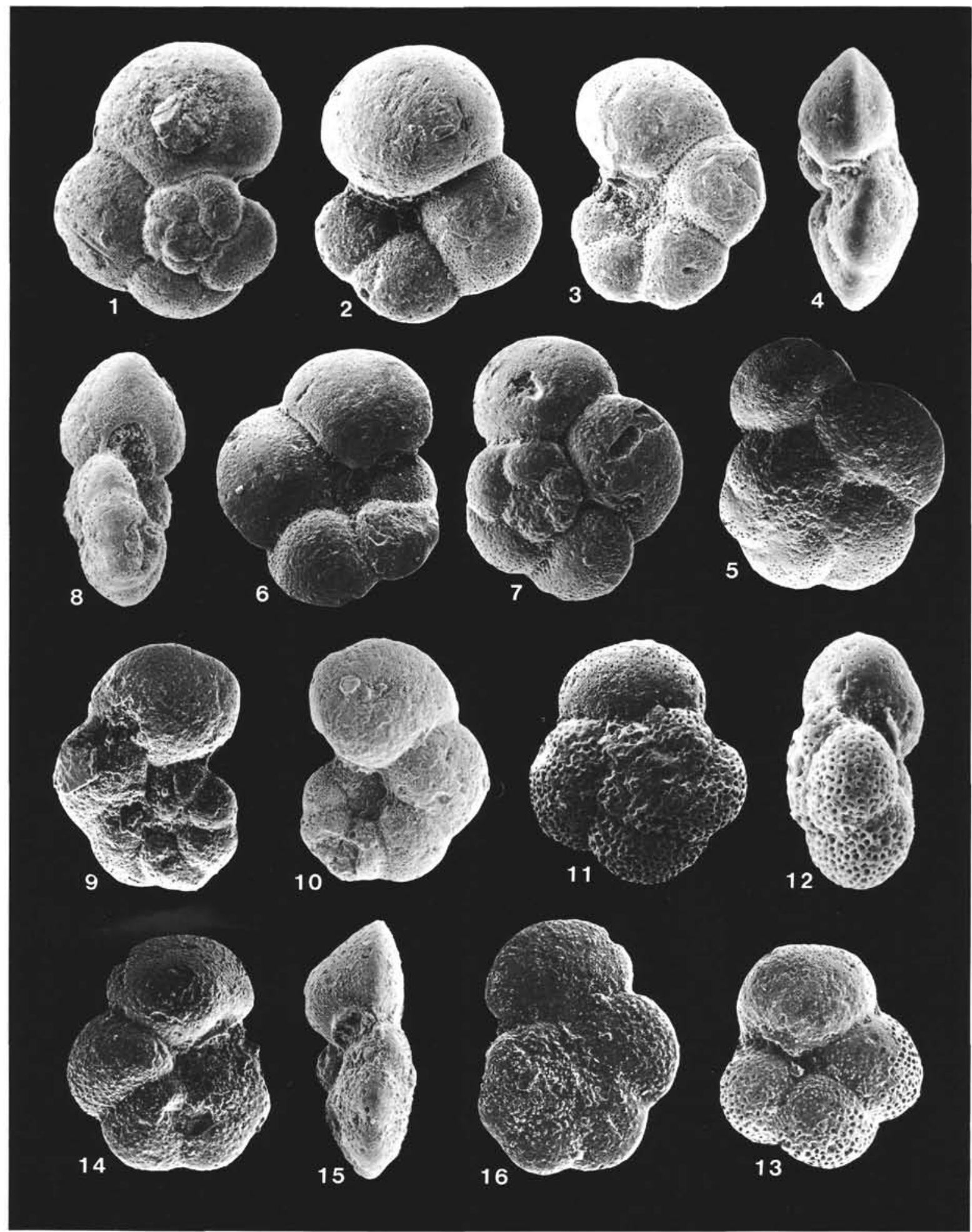

Plate 2. Planorotalites chapmani. 1, 2. Spiral side (1) and umbilical side (2) of specimen with four chambers in the last whorl, $P$. chapmani s.s. in literature. Sample 605-47-3, 60-62 cm; $\times 130$. 3. Umbilical side of specimen with five chambers in the last whorl, $P$. chapmani s.s. in literature. Sample 605-47-3, 60-62 cm; $\times 170.4,5$. Side view (4) and spiral side (5) of specimen with imperforate, acute periphery, $P$. ehrenbergi in literature. Sample 605-46-4, 85-89 cm; $\times 160$. 6, 7. Umbilical side (6) and spiral side (7), $P$. ehrenbergi in literature. Sample 605-46-4, 85-89 cm; $\times 160$. 8, 9, 10. Side view (8), spiral side (9), and umbilical side (10) of specimen showing a tendency to uncoil, $P$. troelseni in literature. Sample $605-46-4,85-89 \mathrm{~cm} ; \times 160$. 11, 12, 13. Spiral side (11), side view (12), and umbilical side (13) of relatively coarsely perforate specimen, $P$. imitata in literature. Note distribution of pores on umbilical side. Sample $605-46-4,85-89 \mathrm{~cm} ; \times 210.14,15,16$. Umbilical side (14), side view (15), and spiral side (16), P. planoconica in literature. Sample 605-46-4, 85-89 cm; $\times 200$. 


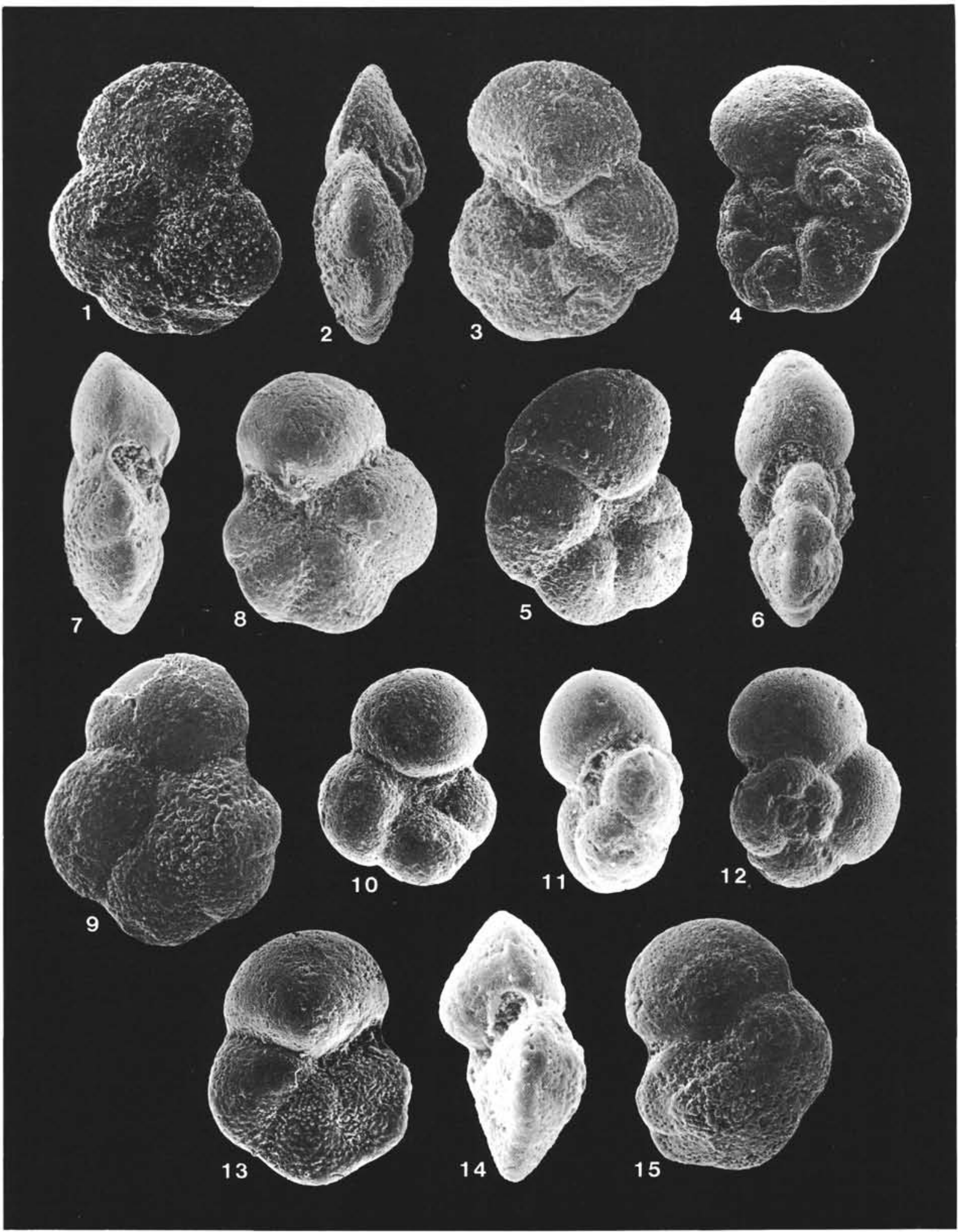

Plate 3. Planorotalites chapmani. 1, 2, 3. Side view (1), umbilical side (2), and spiral side (3) of plano-convex specimen with acute periphery, $P$. hausbergensis in literature. Sample $605-46-4,85-89 \mathrm{~cm} ; \times 200$. 4, 5, 6. Spiral side (4), umbilical side (5), and side view (6) of specimen with onset of keel, transitional between $P$. chapmani s.s. and $P$. troelseni in literature. Sample 605-46-4, 85-89 cm; $\times 160$. 7, 8, 9. Side view (7), umbilical side (8), and spiral side (9) of specimen transitional between $P$. hausbergensis and $P$. planoconica in literature. Sample 605-46-4, 85-89 cm; $\times 220(7,8) ; \times 240(9) .10,11,12$. Umbilical side (10), side view (11), and spiral side (12) of specimen transitional between $P$. chapmani s.s. and $P$. imitata in literature. Sample 605-46-4, $85-89 \mathrm{~cm}$; $\mathrm{f} \times 140$. 13, 14, 15. Umbilical side (13), side view (14), and spiral side (15) of specimen with onset of keel along first three chambers of the last whorl. Sample $605-46-4,85-89 \mathrm{~cm} ; \times 200$. 